\title{
Korelasi antara Kadar Seng Serum dengan Kadar Interleukin-6 dan Skor PELOD-2 pada Sepsis
}

Defranky Theodorus, Dyah Kanya Wati, I Gusti Ngurah Sanjaya Putra, Ida Bagus Subanada, Eka Gunawijaya, Komang Ayu Witarini, Wayan Gustawan

Departemen/KSM Ilmu Kesehatan Anak Fakultas Kedokteran Universitas Udayana/RSUP Sanglah, Denpasar

Latar belakang. Sepsis merupakan penyebab utama morbiditas dan mortalitas pada anak dengan penyakit kritis yang dirawat di unit perawatan intensif anak (UPIA). Pada 24 jam sepsis, terjadi penurunan kadar seng serum dan secara bersamaan terjadi peningkatan kadar interleukin-6 (IL-6) dan skor PELOD-2. Hasil sebaliknya terjadi pada 72 jam sepsis.

Tujuan. Untuk membuktikan korelasi negatif antara kadar seng serum dengan IL-6 dan skor PELOD-2 pada sepsis.

Metode. Penelitian dengan rancangan potong lintang dua kali pengukuran dari Januari - Desember 2019 di UPIA RSUP Sanglah Denpasar. Subjek penelitian adalah anak berusia 29 hari sampai 18 tahun dengan sepsis berdasarkan skor PELOD-2 $\geq 7$ menggunakan metode consecutive sampling. Uji korelasi Pearson untuk menilai korelasi bivariat dan uji multivariat menggunakan uji korelasi parsial.

Hasil. 40 subjek memenuhi kriteria inklusi. Rerata kadar seng serum pada 24 dan 72 jam adalah 59,5 $\mu$ g/dl versus 64,2 $\mu \mathrm{g} / \mathrm{dl}$. Median IL-6 pada 24 dan 72 jam adalah 8,6 pg/dL versus 4,4 pg/dL, rerata skor PELOD-2 24 dan 72 jam adalah 11,2 versus 11,0. Korelasi Pearson kadar seng serum dengan kadar IL-6 pada 24 dan 72 jam adalah $\mathrm{r}=-0,078, \mathrm{p}=0,632$ versus $\mathrm{r}=-0,218, \mathrm{p}=0,178$. Korelasi Pearson kadar seng serum dengan skor PELOD-2 pada 24 dan 72 jam adalah $r=-0,513, p=0,001$ versus $r=0,242, p=0,132$. Analisis korelasi parsial kadar seng serum dengan PELOD-2 pada 24 jam adalah $\mathrm{r}=-0,493, \mathrm{p}=0,002$.

Kesimpulan. Terdapat korelasi negatif sedang bermakna pada 24 jam sepsis antara kadar seng serum dengan skor PELOD-2 setelah mengontrol variabel kendali. Sari Pediatri 2021;23(4):262-9

Kata kunci: sepsis, kadar seng serum, interleukin-6, skor PELOD-2

\section{Correlation between Serum Zinc Levels with Interleukin-6 Levels and PELOD-2 Scores in Sepsis}

Defranky Theodorus, Dyah Kanya Wati, I Gusti Ngurah Sanjaya Putra, Ida Bagus Subanada, Eka Gunawujaya, Komang Ayu Witarini, Wayan Gustawan

Background. Sepsis is the main cause of morbidity and mortality in children with critical illness who are admitted to pediatric intensive care unit. At 24 hours of sepsis, there was a decrease in serum zinc levels along with an increase in interleukin-6 (IL-6) levels and PELOD-2 scores and otherwise at 72 hours.

Objective. To prove a negative correlation between serum zinc levels with IL-6 and PELOD-2 scores in sepsis.

Methods. This design study used a crossectional twice measurement from January to December 2019 at PICU Sanglah Hospital Denpasar. Subjects were children aged 29 days to 18 years with a diagnosis of sepsis based on a PELOD- 2 score $\geq 7$ using a consecutive sampling method. Pearson's correlation test was used to assess the bivariate and the multivariate test used the partial correlation test.

Result. 40 subjects met the inclusion criteria. The mean serum zinc levels at 24 hours and 72 hours were $59.5 \mu \mathrm{g} / \mathrm{dl}$ versus $64.2 \mu \mathrm{g} / \mathrm{dl}$. The median IL-6 at 24 and 72 hours was $8.6 \mathrm{pg} / \mathrm{dL}$ versus $4.4 \mathrm{pg} / \mathrm{dL}$, the mean PELOD-2 scores at 24 and 72 hours were 11.2 versus 11.0 . The Pearson's correlation between serum zinc levels and IL-6 levels at 24 and 72 hours was $r=-0.078, p=0.632$ versus $r=-0.218, p=0.178$. The Pearson correlation between serum zinc levels and PELOD-2 scores at 24 and 72 hours was $r=-0.513, p=0.001$ versus $r=0.242, p=0.132$. The partial correlation analysis of serum zinc levels with PELOD-2 scores at 24 hours was $\mathrm{r}=-0.493, \mathrm{p}=0.002$.

Conclusion. There was a significant negative at 24 hours of sepsis between serum zinc levels and PELOD-2 scores after controlling the control variable. Sari Pediatri 2021;23(4):262-9

Keywords:: sepsis, zinc serum levels, interleukin-6 levels, PELOD-2 score

Alamat korespondensi: Dyah Kanya Wati Departemen/KSM Ilmu Kesehatan Anak Fakultas Kedokteran Universitas Udayana/RSUP Sanglah. Jl. Diponegoro, Denpasar, Bali 80113. Email: dyahpediatric@yahoo.com 
Defranky Theodorus dkk: Korelasi antara kadar seng serum dengan kadar interleukin-6 dan skor Pelod-2 pada sepsis

S epsis merupakan penyebab utama morbiditas dan mortalitas pada anak dengan penyakit kritis yang dirawat di unit perawatan intensif anak (UPIA). ${ }^{1}$ Sepsis menjadi salah satu penyebab utama kematian di seluruh dunia, yaitu sekitar 6 juta kematian pertahun. ${ }^{2}$ Sindrom disfungsi organ multipel merupakan salah satu penanda keparahan suatu penyakit dan merupakan penyebab utama kematian di UPIA. ${ }^{3}$ Di UPIA Rumah Sakit Cipto Mangunkusumo yang merupakan pusat rujukan nasional, 19,3\% dari 502 pasien anak dirawat dengan sepsis dengan angka mortalitas mencapai 54\%. ${ }^{4}$ Di UPIA Rumah Sakit Umum Pusat Sanglah Denpasar pada tahun 2018, prevalensi anak yang mengalami sepsis pada usia 0 tahun hingga 18 tahun sebesar 35,7\% dengan angka mortalitas mencapai $30 \%{ }^{1}$

Pada tahap awal sepsis, terjadi penurunan kadar seng serum bersamaan dengan peningkatan kadar interleukin- 6,5 dan peningkatan skor keparahan penyakit sebagai respon kerusakan jaringan akibat sepsis. ${ }^{6}$ Kadar seng serum menurun dengan cepat setelah redistribusi dari plasma ke jaringan pada permulaan respon fase akut disebut hiposengsemia. ${ }^{7}$

Kadar seng serum rendah berhubungan dengan disfungsi kekebalan tubuh, morbiditas, dan mortalitas akibat sepsis. ${ }^{8}$ Penelitian sebelumnya telah banyak dilakukan untuk mengetahui korelasi kadar seng serum dengan IL-6 dan tingkat kegagalan organ mengunakan skor Sequential Organ Failure Assessment (SOFA) dan Pediatric Risk of Mortality-III (PRISM III), tetapi penelitian yang menghubungkan kadar seng serum dengan skor Pediatric Logistic Organ Dysfunction-2 (PELOD-2) belum pernah dilakukan. Skor PELOD-2 adalah skor yang digunakan untuk menilai tingkat keparahan penyakit dan prediksi kematian berdasarkan pemeriksaan fisis dan laboratorium. ${ }^{9}$ Berdasarkan uraian tersebut maka penulis menganggap pentingnya mengetahui korelasi negatif antara kadar seng serum dengan IL-6 dan skor PELOD-2 pada 24 dan 72 jam sepsis di UPIA RSUP Sanglah Denpasar.

\section{Metode}

Penelitian ini menggunakan rancangan potong lintang dua kali pengukuran dari Januari - Desember 2019 di UPIA RSUP Sanglah Denpasar. Perizinan dan informed consentdidapat daribagian penelitian dan pengembangan
RSUP Sanglah Denpasar. Subjek penelitian adalah anak berusia 29 hari sampai 18 tahun dengan diagnosis sepsis berdasarkan skor PELOD-2 $\geq 7$ menggunakan metode consecutive sampling. Pemeriksaan kadar seng serum, kadar IL-6 dan skor PELOD-2 sebanyak dua kali, yaitu pada 24 jam dan 72 jam.

Kriteria inklusi adalah semua pasien usia 29 hari sampai usia 18 tahun dengan sepsis yang dirawat di UPIA RSUP Sanglah Denpasar dan orangtua/ wali bersedia menandatangani informed consent. Pasien dengan diare, malnutrisi berat, acrodermatitis enteropatica, inflammatory bowel disease, diabetes melitus, hepatitis kronis dan sirosis hepatis, gagal ginjal kronis, sickle cell anemia dan HIV diekslusi karena dapat memengaruhi penurunan kadar seng.

Variabel pertama adalah kadar seng serum, variabel kedua adalah IL-6 dan skor PELOD-2, dan variabel kendali yang dapat memengaruhi penurunan kadar seng adalah usia, jenis kelamin, status gizi, dan status pneumonia.

Kadar seng serum diketahui dari pemeriksaan darah yang diambil sebanyak $5 \mathrm{ml}$ dari vena kubiti, menggunakan metode pemeriksaan trace element Inductively Coupled Plasma Mass Spectrometry (ICPMS) dengan satuan $\mu \mathrm{g} / \mathrm{dl}$. Kadar IL-6 diketahui dari pemeriksaan darah yang diambil dari dari vena kubiti sebanyak $3 \mathrm{ml}$, menggunakan metode pemeriksaan teknik immunoassay enzim sandwich kuantitatif. Skor PELOD-2 rendah apabila skor PELOD-2 7-10 dan skor PELOD-2 tinggi adalah skor $\geq 11$.

Uji normalitas digunakan uji Kolmogorov-Smirnov. Data numerik berdistribusi normal ditampilkan dalam bentuk rerata (Simpang Baku (SB)) dan data tidak berdistribusi normal ditampilkan dalam bentuk median (rentang). Analisis bivariat digunakan uji korelasi Pearson dan analisis multivariat digunakan uji korelasi parsial. Seluruh perhitungan statistik dikerjakan dengan perangkat lunak sistem komputer dan ditampilkan dalam bentuk Tabel dan Grafik.

\section{Hasil}

Subyek penelitian didapatkan 56 subjek yang memenuhi kriteria inklusi dan 16 subjek diekslusi. Total subjek yang diikutsertakan dalam penelitian adalah 40 subjek.

Variabel berskala kategorikal ditampilkan dalam bentuk frekuensi dan persen. Uji normalitas data 
Defranky Theodorus dkk: Korelasi antara kadar seng serum dengan kadar interleukin-6 dan skor Pelod-2 pada sepsis

variabel usia, lama rawat, kadar seng serum, IL-6 dan PELOD-2 24 dan 72 jam didapatkan data yang tidak berdistribusi normal terdapat pada usia dan IL-6. Data ditampilkan dalam bentuk median (Interquartile Range (IQR)). Data berdistribusi normal ditampilkan dalam bentuk rerata (simpang baku).

Tabel 1 menunjukkan distribusi dari karakteristik sampel. Sebagian besar subjek sepsis didapatkan pada perempuan sebesar $60 \%$, sebagian besar dengan gizi kurang sebesar $47,5 \%$, diagnosis terbanyak saat masuk UPIA berasal dari sistem respiratori sebesar $47,5 \%$, penggunaan ventilator $77,5 \%$ dan luaran meninggal $35,0 \%$.

Median usia sepsis 2,3 tahun (rentang 0,2-15,8 tahun) dengan lama rawat rerata 11 hari. Pada 24 jam didapatkan kadar seng serum rendah bersamaan dengan kadar IL-6 dan skor PELOD-2 tinggi dan pada 72 jam kadar seng serum meningkat bersamaan dengan penurunan kadar IL-6 dan skor PELOD-2. Hasil tertera pada Tabel 2.

Hasil uji korelasi Pearson antara kadar seng serum dengan kadar IL-6 pada 24 dan 72 jam didapatkan koefisien korelasi masing-masing $r=-0,078, p=0,632$ versus $\mathrm{r}=-0,218, \mathrm{p}=0,176$. Hasil ini menunjukkan korelasi negatif sangat lemah tidak bermakna antara kadar seng serum dengan IL-6 24 jam dan korelasi negatif lemah tidak bermakna pada 72 jam. Hasil tersebut divisualisasikan menggunakan Scatter plot seperti pada Gambar 1 dan 2.

Hasil uji korelasi Pearson antara kadar seng serum dengan skor PELOD-2 pada 24 dan 72 jam didapatkan koefisien korelasi masing-masing adalah $\mathrm{r}=-0,513, \mathrm{p}=$ 0,001 versus $\mathrm{r}=0.242, \mathrm{p}=0,132$. Hasil ini menunjukkan korelasi negatif sedang bermakna antara kadar seng serum dengan skor PELOD-2 pada 24 jam dan korelasi positif lemah tidak bermakna pada 72 jam. Hasil korelasi tersebut divisualisasikan menggunakan Scatter plot seperti pada Gambar 3 dan 4 .
Tabel 1. Karakteristiksampel

\begin{tabular}{lcc}
\hline Karakteristik & Frekuensi & Persentase \\
\hline Jenis kelamin & & \\
Laki - Laki & 16 & 40,0 \\
Perempuan & 24 & 60,0 \\
Status nutrisi & & \\
Gizi lebih & 9 & 22,5 \\
Gizi baik & 12 & 30,0 \\
Gizi kurang & 19 & 47,5 \\
Diagnosis masuk UPIA & & \\
Respiratori & 19 & 47,5 \\
Kardiovaskular & 4 & 10,0 \\
Gastrohepatologi & 0 & 0,0 \\
Neurologi & 12 & 30,0 \\
Hematologi & 0 & 0,0 \\
Post-surgery & 2 & 5,0 \\
Trauma & 1 & 2,5 \\
Dan lain-lain & 0 & 0,0 \\
Ventilator & & \\
Ya & 31 & 77,5 \\
Tidak & 9 & 22,5 \\
Luaran & & \\
Meninggal & 14 & 35,0 \\
Hidup & 26 & 65,0 \\
\hline
\end{tabular}

Tabel 2. Rerata nilai variabel

\begin{tabular}{lc}
\hline Variabel & Nilai \\
\hline Usia (tahun), median (IQR) & $2,3(0,2-15,8)$ \\
Lama rawat (hari), rerata (SB) & $11,0(0,55)$ \\
Kadar seng, ( $\mu \mathrm{g} / \mathrm{dL})$, rerata (SB) & \\
24 jam & $59,5(24,8)$ \\
72 jam & $64,2(25,4)$ \\
Kadar IL-6 (pg/dL),median (IQR) & \\
24 jam & $8,6(1,06-377,16)$ \\
72 jam & $4,4(1,04-430,32)$ \\
Skor PELOD-2, rerata (SB) & \\
24 jam & $11,2(1,4)$ \\
72 jam & $11,0(1,2)$ \\
\hline
\end{tabular}

Tabel 3. Hasil analisis korelasi parsial kadar seng serum dengan kadar IL-6 dan skor PELOD-2 pada 24 jam setelah mengendalikan usia, jenis kelamin, status gizi, dan status pneumonia

\begin{tabular}{|c|c|c|c|}
\hline Variabel kendali & Korelasi antar vaiabel & $\mathrm{r}$ & $\mathrm{p}$ \\
\hline Usia & & $-0,493$ & 0,002 \\
\hline Jenis kelamin & Kadar seng serum 24 jam & & \\
\hline Status gizi & Skor PELOD-2 24 jam & & \\
\hline Status pneumonia & & & \\
\hline
\end{tabular}


Defranky Theodorus dkk: Korelasi antara kadar seng serum dengan kadar interleukin-6 dan skor Pelod-2 pada sepsis

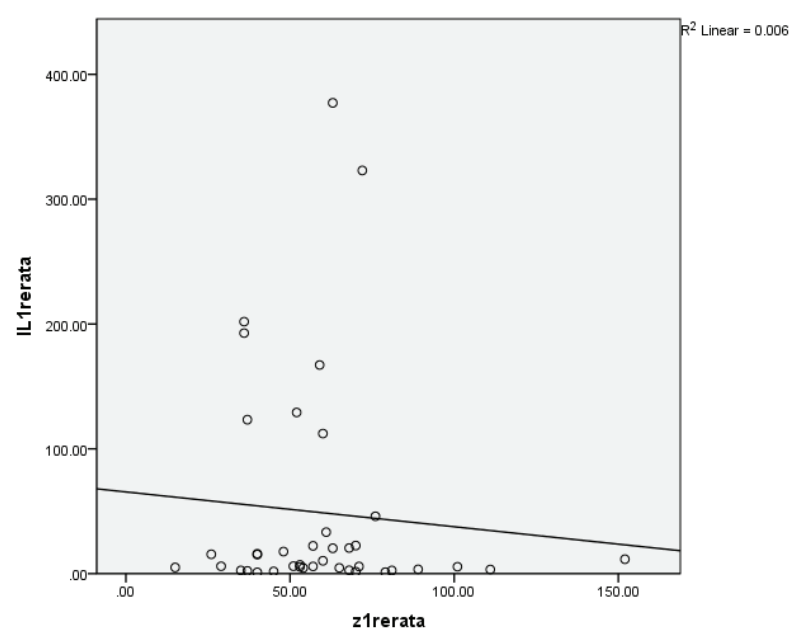

Gambar 1. Scatter plot korelasi kadar seng serum dengan interleukin-6 24 jam

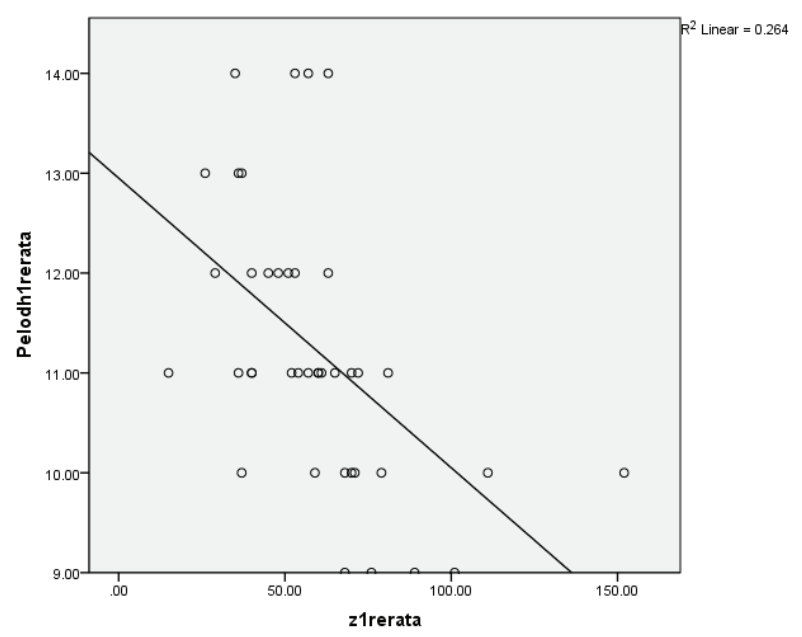

Gambar 3. Scatter plot korelasi kadar seng serum dengan skor PELOD-2 24 jam

Hasil bermakna hanya didapatkan pada korelasi kadar seng serum dengan skor PELOD-2 pada 24 jam. Untuk mengetahui korelasi tersebut apakah dipengaruhi oleh variabel kendali maka dilakukan uji korelasi parsial. Tabel 3 menunjukkan hasil analisis korelasi parsial kadar seng serum dengan kadar skor PELOD-2 pada 24 jam setelah mengendalikan usia, jenis kelamin, status gizi, dan status pneumonia dengan hasil korelasi negatif sedang bermakna.

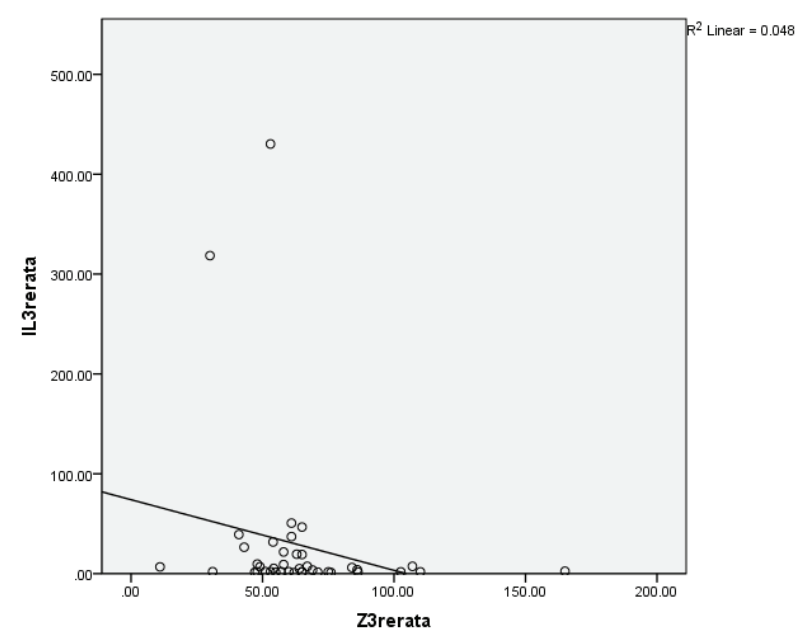

Gambar 2. Scatter plot korelasi kadar seng serum dengan interleukin-6 72 jam

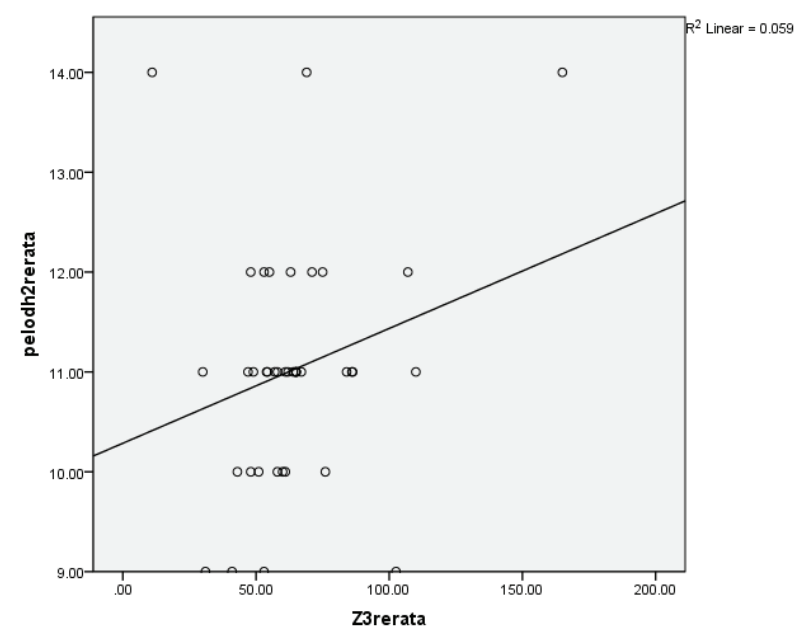

Gambar 4. Scatter plot korelasi kadar seng serum dengan skor PELOD-2 72 jam

\section{Pembahasan}

Penelitian kami mendapatkan sebagian besar sepsis pada anak diderita oleh perempuan sebesar 60\%. Temuan kami serupa dengan Wati dkk ${ }^{1}$ di UPIA RSUP Sanglah Denpasar yang mendapatkan anak perempuan lebih banyak menderita sepsis sebesar $61,5 \%$. Penelitian lain di Mesir juga mendapatkan bahwa perempuan lebih banyak menderita sepsis sebesar 69\%. ${ }^{10}$ Namun, 
temuan kami berbeda dengan yang dilaporkan di UPIA Rumah Sakit Cipto Mangunkusumo (RSCM), yaitu lelaki sebagai penderita sepsis terbanyak pada anak sebesar $56,4 \%{ }^{11}$ dan penelitian lain juga melaporkan lelaki adalah penderita sepsis terbanyak sebesar 55\%. ${ }^{6}$ Perbedaan mendasar hasil yang berbeda ini terdapat pada jumlah sampel penelitian yang sangat besar pada penelitian yang dilakukan di UPIA RSCM. Selain itu, pada penelitian kami subjek dieksklusi karena meninggal sebelum pengambilan sampel kedua yang lebih banyak pada lelaki sebanyak 11 subjek. Berdasarkan teori, jenis kelamin akan membedakan respon imun. Lelaki lebih sering mengalami kondisi penyakit yang lebih berat akibat adanya peningkatan mediator proinflamasi, yaitu TNF $\alpha$, IL-6, IL-10, sedangkan pada perempuan ditemukan lebih banyak mediator antiinflmasi. ${ }^{11}$

Median usia penelitian kami 2,3 tahun. Hasil serupa dengan beberapa penelitian sebelumnya yang melaporkan kelompok usia pasien sakit kritis terbanyak pada rentang 1-11 bulan, diikuti kelompok usia 1 tahun $-<2$ tahun, dan usia $2-<5$ tahun. ${ }^{11}$ Penelitian lain juga melaporkan hasil serupa, yaitu rerata usia sepsis adalah 3 tahun ${ }^{12}$ dan 5,5 tahun. ${ }^{1}$ Berdasarkan teori, anak usia kurang dari lima tahun masih sangat rentan terhadap kejadian infeksi hingga sepsis akibat sistem imun pejamu yang belum matang. ${ }^{11}$

Penelitian kami mendapatkan diagnosis terbanyak saat masuk UPIA adalah pada sistem respiratori sebesar 47,5\%. Hasil ini didukung penelitian sebelumnya pada center yang sama, yaitu diagnosis sistem respiratori merupakan diagnosis terbanyak saat masuk UPIA sebesar 50\%. ${ }^{1}$ Penelitian di RSCM melaporkan hasil serupa, yaitu infeksi terbanyak terdapat pada sistem respiratori sebesar $40 \% .{ }^{12}$ Beberapa faktor fundamental yang saling berkaitan dan memengaruhi insidens pneumonia pada balita adalah kemiskinan yang luas, derajat kesehatan rendah, derajat sosio-ekologi buruk, pembiayaan kesehatan kecil dan proporsi populasi anak yang cukup besar. Faktor risiko pneumonia yang selalu ada meliputi gizi kurang, berat badan lahir rendah, tidak mendapatkan ASI ekslusif, polusi udara dalam ruangan dan pemukiman padat. ${ }^{13}$ Pada penelitian kami, faktor risiko pneumonia yang didapatkan adalah gizi kurang dan tidak mendapatkan ASI ekslusif yang merupakan proporsi terbesar pada masing-masing kelompok (data tidak kami tampilkan), sedangkan faktor risiko lain tidak didata, sehingga tidak dapat kami simpulkan.

Skor PELOD-2 yang lebih tinggi memiliki nilai prediksi mortalitas yang lebih tinggi dan atau lama rawat yang lebih lama. ${ }^{11}$ Teori ini sesuai dengan hasil penelitian kami, yaitu rerata skor PELOD-2 24 jam adalah 11,2 dan pada 72 jam 11,0 dengan luaran meninggal sebesar $35 \%$ dan rerata lama rawat 11 hari. Temuan kami didukung oleh temuan sebelumnya dengan luaran meninggal sebesar 39,3\% dan median lama rawat 10 hari. ${ }^{1}$ Hasil yang sama ini disebabkan tempat penelitian dilakukan pada tempat sama yaitu di UPIA RSUP Sanglah Denpasar sehingga karakteristik demografi subjek penelitian sama. ${ }^{1}$ Penelitian di California, Amerika Serikat melaporkan hasil yang berbeda, dengan luaran meninggal lebih rendah, yaitu $10 \%$, median lama rawat lebih rendah, yaitu 5 hari rentang 3-13 hari. ${ }^{6}$ Penelitian di RSCM dilaporkan luaran meninggal sebesar $10,7 \%$, lama rawat kurang dari 7 hari $(75,5 \%)$, dan hanya $9,6 \%$ yang mengalami rawat lebih dari 14 hari. ${ }^{11}$ Perbedaan dalam luaran meninggal dan lama rawat dapat disebabkan karena pada penelitian di RS Oakland, California, Amerika yang merupakan negara maju. Penanganan sepsis negara maju lebih baik, sedangkan penelitian di RSCM sebagai RS rujukan nasional mengunakan jumlah sampel yang cukup besar, selain memiliki fasilitas yang lebih lengkap dan penanganan sepsis yang lebih baik.

Rerata kadar seng serum penelitian kami pada 24 jam rendah dan meningkat pada 72 jam. Temuan kami didukung oleh Cvijanovich, ${ }^{6}$ yang mendapatkan kadar seng serum rendah pada 24 jam dan meningkat pada 72 jam. Hasil ini sesuai dengan teori. Saat 24 jam menggambarkan kondisi sebenarnya subjek dalam kondisi sepsis tanpa terpengaruh terapi dan merupakan respon fase akut pasien. Kadar seng serum akan meningkat pada 72 jam yang merupakan waktu minimum bagi pasien untuk stabil setelah mendapatkan terapi. Temuan berbeda dilaporkan Wati, ${ }^{14}$ pada center yang sama mendapatkan rerata kadar seng serum 24 jam rendah dan semakin rendah pada 72 jam. Hal ini disebabkan perbedaan pada subjek penelitian. Penelitian Wati, ${ }^{14}$ menggunakan subjek dengan ventilator di UPIA. Penggunaan ventilator di UPIA akan menyebabkan proses inflamasi dan kemungkinan penurunan kadar seng serum selain disebabkan oleh sepsis dapat disebabkan proses inflamasi karena pemakaian ventilator. ${ }^{14}$

Berdasarkan teori reaksi tubuh terhadap infeksi fase akut adalah hiposengsemia dengan tujuan mencegah pertumbuhan patogen dan berhubungan dengan pencegahan terhadap kerusakan jaringan selama proses infeksi atau inflamasi. Patogen menggunakan 
seng untuk berkembang biak, respon tubuh adalah membatasi penggunaan seng. Jumlah patogen akan berkurang pada 72 jam setelah subjek mendapatkan terapi dan terjadi mekanisme umpan balik seng dari hati ke serum sehingga kadar seng serum akan meningkat. ${ }^{15}$

Rerata kadar IL-6 menurun pada pengukuran kedua pada penelitian ini. Hasil ini serupa dengan yang dilaporkan oleh Wati, ${ }^{14}$ dan Cvijanovich, ${ }^{6}$ bahwa rerata kadar IL-6 tinggi pada 24 jam dan menurun pada 72 jam. IL-6 merupakan sitokin proinflamasi yang bertanggung jawab terhadap sebagian besar respon fase akut. Adanya patogen dalam tubuh akan memicu proses inflamasi dan respon imun. ${ }^{15}$ Semakin luas proses inflamasi, semakin tinggi kadar IL-6. Respon imun terhadap adanya inflamasi adalah penurunan aktivitas timulin, yang dibutuhkan untuk pematangan sel T-helper (Th) menyebabkan ketidakseimbangan antara sel Th1 dan Th2 sehingga terjadi penurunan jumlah sel $T$ naif dan jumlah sel $T$ sitotoksik, serta penurunan aktivitas sel natural killer, meyebabkan terjadi penurunan produksi IFN- $\gamma$ dan IL-2, yang merupakan produk sel Th1, sedangkan produksi sel Th2 meningkat seperti IL-4, IL-6, dan IL-10. Pada 72 jam setelah subjek mendapat terapi, jumlah patogen akan berkurang, kerusakan jaringan berkurang, dan proses inflamasi jaringan berkurang sehingga kadar interlukin-6 akan menurun. ${ }^{16}$

Hasil uji korelasi Pearson antara kadar seng serum dengan kadar IL-6 pada 24 jam penelitian kami adalah korelasi negatif sangat lemah tidak bermakna, sedangkan pada 72 jam adalah korelasi lemah tidak bermakna. Hasil ini memberikan gambaran saat terdiagnosis sepsis dalam 24 jam pertama kadar seng serum rendah bersamaan dengan kadar IL-6 tinggi dan berbanding terbalik pada 72 jam.

Reaksi tubuh terhadap infeksi fase akut adalah hiposengsemia dengan tujuan mencegah pertumbuhan patogen dan bertindak sebagai pencegahan terhadap kerusakan jaringan. Patogen menggunakan seng untuk berkembang biak, respon tubuh adalah membatasi penggunaan seng dengan mekanisme hiposengsemia yang akan memodulasi sitokin proinflamasi, salah satunya IL-6. Jumlah patogen akan berkurang pada 72 jam setelah subjek mendapatkan terapi dan terjadi mekanisme umpan balik seng dari hati ke serum sehingga kadar seng serum akan meningkat bersamaan dengan kadar IL-6 rendah sebagai respon penurunan kerusakan jaringan. ${ }^{15}$
Hasil penelitian kami serupa dengan beberapa penelitian sebelumnya. Cvijanovich, ${ }^{6}$ mendapatkan rerata kadar IL-6 lebih tinggi pada 24 jam dan menurun pada 72 jam. Penelitian Wati, ${ }^{14}$ pada center yang sama memberikan hasil yang berbeda pada pengukuran 72 jam, yang mendapatkan kadar IL-6 24 jam rendah dan semakin rendah pada 72 jam. Hasil yang berbeda pada penelitian Wati, ${ }^{14}$ dapat disebabkan perbedaan dalam subjek penelitian. Wati, ${ }^{14}$ menggunakan subjek dengan menggunakan ventilator di UPIA. Penggunaan ventilator di UPIA akan menyebabkan proses inflamasi dan kemungkinan besar penurunan kadar seng serum selain disebabkan oleh sepsis dapat disebabkan proses inflamasi karena penggunaan ventilator, sehingga kadar seng serum akan semakin rendah pada 72 jam sepsis. ${ }^{14}$

Hasil uji korelasi Pearson antara kadar seng serum dengan kadar skor PELOD-2 pada 24 jam penelitian kami adalah korelasi negatif sedang bermakna, sedangkan pada 72 jam adalah korelasi positif lemah tidak bermakna. Korelasi positif pada 72 jam tidak sesuai dengan teori, hasil tersebut menunjukkan terdapat hubungan searah yang berarti peningkatan kadar seng serum akan disertai peningkatan skor PELOD-2, begitupula sebaliknya. Korelasi ini tidak sesuai dengan hasil penelitian kami, yaitu pada 24 jam kadar seng serum rendah bersamaan dengan skor PELOD-2 tinggi dan pada 72 jam kadar seng serum meningkat bersamaan dengan skor PELOD-2 rendah.

Identifikasi ketidakseusain hasil ini disebabkan telah terjadi hubungan palsu dengan didapatkan satu subjek dengan skor PELOD-2 tinggi disertai kadar seng serum tinggi. Scater plot membuktikan korelasi kedua variabel ini tidak masuk akal hanya karena satu pencaran ekstrem. Pada data tersebut kami temukan kadar seng serum rendah pada 24 jam dan meningkat pada 72 jam dengan nilai skor PELOD-2 yang tinggi pada pengukuran 72 jam yang menandakan proses kerusakan jaringan yang semakin luas.

Hasil ini memberikan gambaran saat terdiagnosis sepsis pada 24 jam pertama kadar seng serum rendah secara bersamaan dengan skor PELOD-2 tinggi dan akan berbanding terbalik pada 72 jam. Pada sepsis terjadi infeksi sistemik dari respon inflamasi host dan cedera jaringan. Reaksi tubuh terhadap infeksi fase akut adalah hiposengsemia dengan tujuan mencegah pertumbuhan patogen dan bertindak sebagai pencegahan terhadap kerusakan jaringan lebih lanjut. Ketika sistem imun 
tidak efektif mengeliminasi antigen, proses inflamasi menjadi tidak terkendali dan menyebabkan kegagalan sistem organ yang di tandai dengan skor PELOD-2 tinggi pada 24 jam. Jumlah patogen akan berkurang pada 72 jam setelah subjek mendapatkan terapi dan terjadi mekanisme umpan balik seng dari hati ke serum sehingga kadar seng serum akan meningkat secara bersamaan terjadi skor PELOD-2 turun sebagai respon perbaikan organ yang terlibat selama sepsis. ${ }^{15}$

Hasil penelitian kami tidak dapat dibandingkan dengan penelitian lain yang mencari korelasi kadar seng serum dengan skor PELOD-2 pada 24 dan 72 jam sepsis karena sepengetahuan peneliti belum ada penelitian serupa hingga saat ini. Namun begitu, penilaian tingkat keparahan penyakit menggunakan sistem skoring yang sama baiknya dengan skoring PELOD-2 telah dilaporkan oleh Cvijanovich ${ }^{6}$ yang menggunakan skor PRISM III. Penelitian tersebut mendapatkan korelasi negatif bermakna kadar seng serum dengan skor PRISM III pada 24 dan 72 jam. Kadar seng serum pada 24 jam rendah bersamaan dengan skor PRISM III tinggi dan pada 72 jam kadar seng serum meningkat bersamaan penurunan skor PRISM III.

Analisis korelasi parsial menunjukkan korelasi bermakna hanya terdapat antara kadar seng serum dengan skor PELOD-2 pada 24 jam yaitu korelasi negatif sedang bermakna. Hasil ini menunjukkan bahwa penurunan kadar seng serum pada penelitian kami disebabkan oleh sepsis tanpa dipengaruhi variabel kendali sehingga menjadi informasi penting bahwa kadar seng serum rendah terjadi bersamaan dengan skor PELOD-2 tinggi pada 24 jam sepsis tanpa dipengaruhi usia, jenis kelamin, status gizi, dan status pneumonia.

Hasil ini konsisten dengan penelitian yang telah dilakukan sebelumnya terutama pada 24 jam sepsis sehingga dapat menjadi informasi penting dalam penanganan pasien sepsis di UPIA. Hasil penelitian ini dapat dijadikan acuan dalam memberikan komunikasi, informasi, dan edukasi kepada orangtua mengenai risiko dan dampak buruk kadar seng serum rendah dan skor PELOD-2 tinggi pada 24 jam sepsis, sehingga perlu menjadi perhatian khusus. Penggunaan kadar seng serum dalam menentukan prognosis pada pasien sepsis dapat dipertimbangkan.

Korelasi antara kadar seng serum dengan IL-6 tidak konsisten dengan beberapa penelitian sebelumnya. Hasil berbeda ini menggambarkan kadar IL-6 tidak dapat menggambarkan kondisi sepsis yang sebenarnya, sehingga tidak dapat dijadikan acuan dalam menggambarkan kondisi akut pasien sepsis. IL-6 memiliki kadar puncak yang singkat dalam darah, yaitu meningkat pada dua jam setelah host terinfeksi patogen dan akan menurun dengan cepat setelah enam jam. ${ }^{14}$

Penelitian ini memiliki beberapa kelemahan, antara lain, penelitian korelasi tidak mengetahui variabel yang merupakan faktor risiko dan variabel efek hanya menentukan hubungan searah atau berlawanan arah tanpa menunjukkan hubungan yang bersifat kausal. Desain penelitian digunakan desain potong lintang sehingga tidak menggambarkan perjalanan penyakit. Penelitian ini juga dilakukan di ruang UPIA yang tidak memperhitungkan waktu transit dari ruang Unit Gawat Darurat ke ruang UPIA. Selain itu, rumah sakit tempat penelitian dilakukan merupakan RS tersier yang merupakan RS rujukan sehingga kondisi sepsis yang terjadi belum tentu mencerminkan kondisi sepsis pada fase akut.

\section{Kesimpulan}

Penelitian ini menyimpulkan bahwa terdapat korelasi negatif sangat lemah tidak bermakna antara kadar seng serum dengan kadar IL-6 pada 24 jam sepsis dan korelasi negatif lemah tidak bermakna pada 72 jam sepsis setelah mengontrol variabel kendali. Terdapat korelasi negatif sedang bermakna antara kadar seng serum dengan skor PELOD-2 pada 24 jam sepsis dan korelasi negatif lemah tidak bermakna antara kadar seng serum dengan skor PELOD-2 pada 72 jam sepsis setelah mengontrol variabel kendali.

\section{Daftar pustaka}

1. Wati DK, Hartawan INB, Suparyatha IBG, Mahalini DS, Pratiwi IGAPE., Utama IMGDL. Sari Pediatri 2019;21: 152-8.

2. World Health Organization. Improving the prevention, diagnosis and clinical management of sepsis. Service delivery and safety 2017. Diunduh pada 2 Januari 2019. Didapat dari: URL: https://www.who.int/ servicedeliverysafety/areas/sepsis/en/.

3. Proulx F, Joyal JS, Mariscalco MM, Leterurtre S, Leclerc F, Lacroix J. The pediatric multiple organ dysfunction syndrome. Pediatr Crit Care Med 2009;10:12-22.

4. Ikatan Dokter Anak Indonesia. Pedoman nasional pelayanan kedokteran Ikatan Dokter Anak Indonesia: Diagnosis dan tatalaksana sepsis pada anak. Badan penerbit Ikatan Dokter Anak Indonesia: 2016. 
5. Quinton LJ, Blahna MT, Jones MR, dkk. Hepatocyte-specific mutation of both NF-kappaB RelA and STAT3 abrogates the acute phase response in mice. J Clin Invest 2012;122:1758-63.

6. Cvijanovich NZ, King JC, Flori HR, Gildengorin G, Wong HR. Zinc homeostasis in pediatric critical illness. Pediatr Crit Care Med 2009;10:29-34.

7. Moshage H. Cytokines and the hepatic acute phase response. J Pathol 1997;181:257-66.

8. Hoeger J, Simon TP, Beeker T, Marx G, Haase H, Schuerholz T. Persistent low serum zinc is associated with reccurent sepsis in critically ill patients - A pilot study. Plos ONE 2017;12: $1-10$.

9. Bayu BT, Martuti S, Salimo H. Perbandingan prediktor mortalitas skor PRISM III dan PELOD-2 pada anak sakit kritis non-bedah. Sari Pediatri 2018.;19: 284-89.

10. Helmy TA, Beshey BN. Correlation between serum zinc and mortality in septic patients. Int J Adv Res 2016;4:1514-17.

11. Dewi R, Farimatuzzuhroh. Profil pasien sakit kritis yang dirawat di Pediaric Intensive Care Unit Rumah Sakit Cipto Mangunkusumo berdasarkan sistem skoring Pediatric Logistic Organ ysfunction-2. Sari Pediatri 2019;21:37-43.

12. Wulandari A, Martuti S, Pudjiastuti. Perkembangan diagnosis sepsis pada anak. Sari Pediatri 2017;19:237-44.

13. Said M. Pengendalian pneumonia anak-balita dalam rangka pencapaian MDG4. Bul Jendela Epidemiologi 2010;3:16-21.

14. Wati DK, Sidiartha L, Tunas K, Setiawan A. Correlation between zinc plasma level to inflammation response of patient with ventilator in pediatrics intensive care unit. Crit Care Shock 2019;22:161-71.

15. Alker W, Haase H. Zinc and sepsis. Nutrients 2018;10: 1-17.

16. Gammoh NZ, Rink L. Zinc in infection and inflammation. Nutrients 2017;9:1-25. 